\title{
BATU TETERUGA DAN CERITA RAKYAT SUKU SOBEY
}

\author{
(Batu Teteruga and The Sobey Tribe Folktale)
}

\author{
Rini Maryone \\ Balai Arkeologi Papua \\ Jl. Isele Waena Kampung, Heram, Kota jayapura, Provinsi Papua \\ Pos-el : Rinimaryone1972@gmail.com
}

\begin{tabular}{l}
\multicolumn{1}{c}{ INFO ARTIKEL } \\
\hline Histori Artikel \\
Diterima : 1 Juni 2021 \\
Direvisi : 16 Juni 2021 \\
Disetujui : 27 Juni 2021 \\
\hline
\end{tabular}

Keywords:

The Sobey Tribe,

Folktale, Stones

\section{Kata kunci:}

Batu teteruga, cerita

rakyat, Suku Sobey

\begin{abstract}
Megalithic dwellings in Papua related to folktale are very much traced from each region. These folktale are not only told by the community but there is historical evidence in the form of natural stone buildings. Which according to archaeology is called megalithic buildings. The stone is believed to be a deformed turtle. This research was conducted in Kampung Bagaiserwar Sarmi Kota district, Sarmi Regency, Papua Province. In this paper the author uses the method of ethnoarkeological approach. This research is also conducted in two stages, namely data collection and data processing. Data collection is done in several ways, namely: surveys, interviews and conducting library studies. The final stage is data processing, after all the collected data is then described, analyzed and interpreted. By using this method, you can also find out the megalithic remains of the suspect stone /turtle and folktale of the Sobey tribe in Sarmi Regency and can know what cultural values are contained in the megalithic dwellings and folktale of teteruga/ turtles / in the Sobey tribe in Sarmi
\end{abstract}

\begin{abstract}
ABSTRAK
Tinggalan megalitik di Papua yang berkaitan dengan cerita rakyat sangat banyak kalau ditelusuri dari setiap daerah. Cerita-cerita rakyat tersebut tidak hanya diceritakan begitu saja oleh masyarakat tetapi ada bukti sejarahnya berupa bangunan batu-batu alam. Yang menurut ilmu arkeologi disebut bagunan megalitik. Batu tersebut dipercaya sebagai teterugal penyu yang berubah wujud. Penelitian ini dilakukan di Kampung Bagaiserwar distrik Sarmi Kota, Kabupaten Sarmi, Provinsi Papua. Dalam tulisan ini penulis menggunakan metode pendekatan etnoarkeologi. Penelitian ini pula, dilakukan dengan dua tahap yaitu pengumpulan data dan pengolahan data. Pengumpulan data dilakukan dengan beberapa cara yaitu : survei, wawancara dan melakukan studi pustaka. Tahap akhir adalah pengolahan data, setelah semua data terkumpul kemudian dideskripsikan, dianalisis dan diinterpretasikan. Dengan menggunakan metode ini pula dapat mengetahui tinggalan megalitik batu teteruga/penyu dan cerita rakyat Suku Sobey di Kabupaten Sarmi serta dapat mengetahui nilai-nilai budaya apa yang terkandung dalam tinggalan megalitik dan cerita rakyat teteruga/penyu/ pada Suku Sobey di Kabupaten Sarmi.
\end{abstract}




\section{PENDAHULUAN}

Indonesia dikenal sebagai bangsa yang memiliki kekayaan warisan budaya yang bernilai tinggi. Warisan budaya tersebut ada yang berupa bangunan atau monumen, kesenian, naskah-naskah kuno dan jenis-jenis budaya lainya (Sumarsih, 1985 : 5). Warisan budaya berupa bangunan atau monumen yang dikenal yaitu tinggalan megalitik. Warisan budaya tersebut merupakan kebudayan Nusantara yang lekat dengan tradisi megalitik. Warisan budaya megalitik ini tak berhenti pada zaman prasejarah saja, namun tradisi tersebut terus berkembang hingga zaman sejarah (Hoop, 1932 : 101). Tradisi megalitik merupakan tradisi yang mencerminkan perjalanan peradaban suatu masyarakat.

Tradisi megalitik adalah salah satu bentuk ciptaan manusia yang dicirikan oleh benda-benda megalit berupa bangunan dari batu. Istilah megalitik berasal dari kata mega yang berarti besar, dan lithos yang berarti batu. Pendirian bangunan megaltik selalu berdasarkan pada kepercayaan akan adanya hubungan antara yang hidup dan yang sudah meninggal. Kepercayaan ini menganggap bahwa roh seseorang tidak lenyap pada saat orang meninggal. Roh dianggap mempunyai kehidupan di alamnya tersendiri sesudah orang meninggal. Kemudian muncul kepercayaan bahwa roh-roh tersebut masih selalu berhubungan dengan orang yang masih hidup, dan dianggap mempunyai pengaruh yang kuat terhadap kesejahteraan masyarakat. Pengertian megalit sebagai batu besar dalam kenyataannya tidak selalu diterapkan sesuai dengan arti yang sebenarnya. Namun menurut Wagner dalam Indonesia: The Art of an Island Group menyatakan bahwa bangunan megalitik tidak hanya batu besar akan tetapi batu kecil dan bahkan tanpa monumen dapat dikatakan berciri megalitik apabila benda tersebut dimaksud untuk pemujaan arwah nenek moyang (Wagner, 1962: 72).

Tradisi megalitik di dunia ini terkandung dalam alam pikiran yang bersifat religius. Kepercayaan tersebut juga dimiliki oleh bangsa-bangsa lainnya di Asia Tenggara dan Pasifik. Bangunan-bangunan megalitik tersebar hampir di seluruh Kepulauan Indonesia. Geldern (1984 : 306312). Geldern berpendapat, bahwa tradisi ini dibawa oleh penutur Austronesia. Diduga, bahwa Indonesia yang menerima tradisi megalitik dalam dua gelombang, yaitu sebagai berikut: Megalitik Tua yang diwakili antara lain oleh menhir, undak batu, dan patung-patung simbolis-monumental 
bersama-sama dengan pendukung kebudayaan beliung yang diperkirakan berusia 2500 - 1500 Sebelum Masehi dan dimasukkannya dalam masa Neolitik. Megalitik tua ini dibawa oleh para imigran melalui Tonkin menuju Malaysia Barat dan masuk ke Indonenia melalui Sumatera. Dari Sumatera sebagian berlanjut ke Jawa dan terus ke Nusa Tenggara, sedangkan sebagian lagi menyebar ke Kalimantan terus ke utara. Megalitik Muda yang diwakili antara lain oleh peti kubur batu, dolmen semu, sarkofagus, yang berkembang dalam masa yang telah mengenal perunggu dan berusia sekitar awal millenium pertama Sebelum Masehi hingga abad-abad pertama Masehi (Soejono, 1984: 223 - 224). Megalitik muda ini diperkirakan datang bersama-sama dengan kebudayaan Dong Son.

Di Indonesia keberadaaan bengunanbangunan megalitik sangatlah umum. Sampai saat ini belum dapat dihitung secara pasti jumlahnya. Namun demikian hasil penelitian telah menunjukan sebaran yang sangat luas, baik yang dimulai dari Sumatera, Jawa, Sulawesi, Bali, Sumba, Sumbawa, Flores, Timor, Sabu, Maluku, dan Papua (Geldern, 1984: 306-312),

Papua menerima pengaruh megalitik dari Asia Tenggara lewat rute barat melalui
Kepulauan Indonesia bagian selatan, Maluku, selanjutnya memasuki Kepala Burung; dan pengaruh megalitik juga menyebar melalui Mikronesia, sebelum menuju ke barat menuju Sepik di Papua Nugini melalui Filipina, Sulawesi Utara, dan Halmahera (Soejono, 1984 : 30). Bentuk megalitik di Papua agak berbeda dengan bentuk megalitik yang ditemukan di wilayah Indonesia bagian barat dan Sulawesi. Megalitik di Papua lebih dicirikan oleh pola yang sederhana yang mirip dengan bentukbentuk yang ada di Maluku dan Nusa Tenggara Timur (Prasetyo, 2011: 88).

$$
\text { Tradisi megalitik di Papua }
$$
merupakan kegiatan ritual dengan menggunakan medium batu-batu alam seperti stalagmit dan stalagtit dalam guagua, dolmen, batu pahatan dan batu-batu alam lainnya yang dianggap sebagai jelmaan roh-roh nenek moyang, yang dilakukan baik secara perorangan dan kelompok. Kegiatan ritual ini menunjukkan adanya tradisi berlanjut dan sekaligus dapat menggambarkan sistem religi masa lampau Papua yang masih bertahan ditengah kehidupan masyarakat yang sudah berkembang dan sudah memiliki suatu kepercayaan hidup yaitu Kristen dan Islam. 
Terkait dengan judul batu teteruga atau penyu dan cerita rakyat masyarakat Suku Sobey, adalah cerita pada masa lampau yang menjadi ciri khas dari masyarakat Sarmi yang memiliki kultur budaya yang beraneka ragam mencakup kekayaan budaya dan sejarah. Cerita rakyat teteruga ini merupakan sebuah kisah yang diangkat dari pemikiran fiktif dan kisah nyata dibarengi dengan pesan moral yang mengandung makna kehidupan dan tata cara dalam berinteraksi dengan makluk hidup. Cerita rakyat ini menunjukan kepada cerita yang merupakan bagian dari rakyat, yaitu hasil sastra yang termasuk ke dalam cakupan foklor. Cerita rakyat tersebut merupakan pernyataan sesuatu budaya kelompok manusia yang mengisahkan berbagai ragam peristiwa yang berkaitan dengan mereka, baik secara langsung atau tidak. Cerita rakyat ini juga merupakan suatu bentuk karya sastra lisan yang lahir dan berkembang dari masyarakat tradisional yang disebarkan dalam bentuk relatif tetap dan di antara kolektif tertentu dari waktu yang cukup lama dengan menggunakan kata klise (Danandjaja, 2007: 3-4).

Batu teteruga dan cerita rakyat telah ditulis dalam beberapa jurnal ilmiah seperti: "Batu Mawe di Teluk Wondama" (Maryone, 2019:101-109), “Tinggalan Megalitik Batu
Sukun Mengungkapkan Cerita Rakyat di Kampung Yapase" (Maryone, 2019 :71-79), "Megalitik dan Cerita Rakyat Suku Baham di Gua Sosoraweru Fakfak" (Maryone. 2014 : 113-120). Tinggalan-tinggalan megalitik tersebut dapat mengungkapkan cerita rakyat di beberapa daerah di wilayah Papua.

Pada umumnya cerita rakyat mengisahkan tentang suatu kejadian di suatu tempat atau asal muasal suatu tempat. Tokoh-tokoh yang dimunculkan dalam cerita rakyat umumnya diwujudkan dalam bentuk binatang, manusia maupun dewa. Cerita rakyat dapat diartikan sebagai ekspresi budaya suatu masyarakat melalui bahasa dan susunan nilai sosial masyarakat tersebut. Cerita rakyat itu sendiri mempunyai kegunaan dalam kehidupan bersama, sebagai alat pendidikan, hiburan, protes sosial dan proyeksi suatu keinginan yang terpendam. Sedangkan cerita rakyat bersifat pralogis yaitu logika yang khusus dan kadang berbeda dengan logika umum. Penelitian tentang cerita rakyat telah banyak dilakukan untuk berbagai macam tujuan (Danandjaja dalam Lestari, 2012 : 21).

Cerita rakyat ini pula, dapat digali dari berbagai sumber, salah satu sumber yang penulis pakai di sini adalah berasal dari tinggalan megalitik yaitu batu-batu alam yang disebut batu monolit. Dalam penulisan

Batu Teteruga Dan Cerita Rakyat Suku Sobey 
ini ada dua permasalahan yang diangkat yaitu, bagaimana tinggalan mengalitik dan cerita rakyat batu teteruga pada Suku Sobey di Kabupaten Sarmi dan bagaimana nilainilai budaya yang terkandung dalam tinggalan megalitik dan cerita rakyat batu teteruga. Tujuan penulisan ini adalah untuk mengetahui tinggalan megalitik dan cerita rakyat batu teteruga dan mengetahui nilainilai budaya apa yang terkandung dalam tinggalan megalitik dan cerita rakyat batu teteruga yang terdapat pada Suku Sobey di Kabupaten Sarmi.

Dalam penelitian ini menggunakan metode pendekatan etnoarkeologi. Menurut Sukendar dalam Wibowo (2015: 17) etnoarkeologi adalah studi arkeologi sebagai analogi untuk membantu memecahkan masalah-masalah arkeologi. Kajian etnoarkeologi bukan untuk menjelaskan gejala yang dapat diamati saat ini (data etnografi), tetapi sekedar memberikan gambaran kemungkinan adanya persamaan antara gejala budaya masa lampau dan masa kini. Penelitian ini, dilakukan dengan dua tahap yaitu pengumpulan data dan pengolahan data. Pengumpulan data dilakukan dengan beberapa cara yaitu: survei dengan pengamatan langsung terhadap objek yang diteliti. Wawancara dengan tokoh adat dan masyarakat guna mendapatkan informasi tentang objek yang diteliti. Melakukan studi pustaka dengan menelaah beberapa pustaka yang berkaitan dengan objek penelitian setelah semua data yang dibutuhkan terkumpul. Tahap akhir adalah pengolahan data, setelah semua data terkumpul kemudian dideskripsikan, dianalisis dan diinterpretasikan.

\section{PEMBAHASAN}

Nama Sarmi merupakan singkatan dari nama suku-suku besar, yakni Sobey, Armati, Rumbuai, Manirem, dan Isirawa. Keberadaan suku-suku tersebut telah lama menjadi perhatian antropolog Belanda Van Kouhen Houven, yang kemudian memberikan nama kediaman mereka tersebut dengan singkatan nama Sarmi. Walaupun singkatan Sarmi sebenarnya belum mencerminkan suku-suku disana mengingat di wilayah ini terdapat 87 bahasa yang dipergunakan dari bahasa yang ada, paling tidak bisa disimpulkan terdapat 87 suku, dan setiap suku mempunyai bahasa sendiri-sendiri (Lekitoo, $2005: 10$ ). 


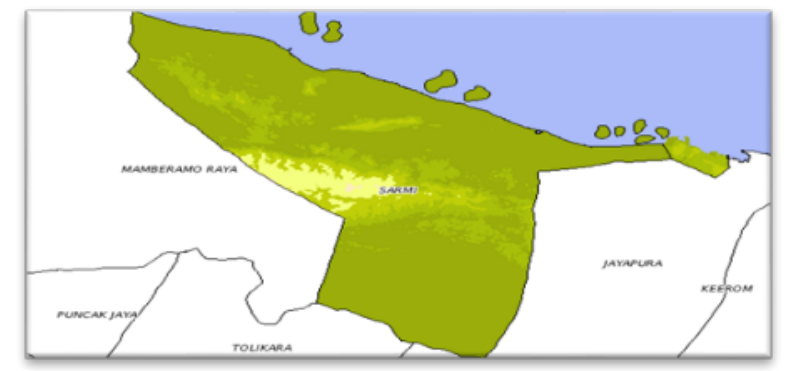

Gambar 1. Kabupaten Sarmi

(Sumber: dokumentasi penelitian 2016)

Bagaiserwar termasuk dalam Suku Sobey suku ini tersebar di wilayah Distrik Sarmi kota, mereka juga disebut orang Biga yang juga mendiami daerah pantai utara sebelah barat, yaitu di sebelah timur Kabupaten Sarmi. Suku Sobey mendiami desa-desa yaitu antara lain Sarmi, Sawar, Wakde, dan juga termasuk Bagiserwar.

\section{Cerita Batu Teteruga}

Batu teteruga disebut juga batu penyu atau Lensau fatiatu, ditemukan di Kampung Bagaiserwar, Distrik Sarmi Kota Kabupaten Sarmi. Batu teteruga ini merupakan batu pasir berwarna hitam keabuan dengan panjang $160 \mathrm{~cm}$, lebar 140 $\mathrm{cm}$ dan tebal $70 \mathrm{~cm}$. Bagian permukaan batu cukup datar dan terdapat lubang-lubang bulat di atasnya.

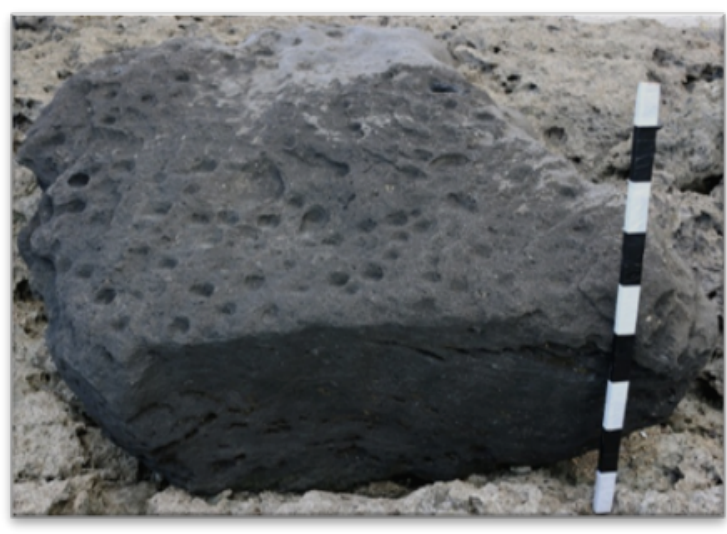

Gambar 2: Batu Teteruga (Dokumentasi: Rini Maryone)

Batu teteruga oleh masyarakat, dipercaya bahwa batu tersebut sebagai perubahan wujud teteruga yang menjadi batu. Adapun kisah tentang batu teteruga atau lensau fatiafo diawali dari suatu peristiwa di pesisir pantai di tempat batu teteruga berada. Pada waktu itu, berkumpullah sejumlah binatang seperti kasuari, anjing, teteruga dan sejumlah binatang lainnya, dan dalam perkumpulan tersebut binatang-binatang ini mulai bernyanyi, dan ketika anjing mulai mengeluarkan suaranya membuat suasana menjadi ricuh karena binatang lain tertawa mendengar suara anjing yang aneh itu, dan ini membuat anjing menjadi tersinggung dan mulai mengigit, dan saat itu semua binatang lari terpencar termasuk kasuari yang dengan kaki panjangnya mulai bergerak lari, namun ia menginjak kepala teteruga dan jarinya Batu Teteruga Dan Cerita Rakyat Suku Sobey 
tertancap ke mata teteruga sehingga mengakibatkan bola mata teteruga tercabut karena tersangkut di jari kaki kasuari yang lari ke hutan dan membawa serta mata teteruga tersebut, kemudian teteruga tersebut berubah menjadi batu. Batu teteruga tersebut hingga kini masih dipercaya oleh beberapa kelompok mayarakat dari Suku Sobey sebagai objek yang mendatangkan rejeki teteruga saat mencari, yaitu dengan cara mereka memecahkan sedikit batu tersebut untuk dibawa serta dalam pencarian teteruga sehingga mereka akan berhasil (Maryone, 2016: 28).

Dalam cerita masyarakat setempat bahwa batu ini juga dipercaya sebagai objek yang mendatangkan teteruga saat mencari. Apabila mereka mau mencari teteruga mereka memecahkan sedikit bagian dari batu tersebut untuk dibawa serta dalam aktivitas pencarian teteruga. Kepercayaan mereka bahwa apabila mereka membawa serta batu teteruga tersebut nantinya mereka akan berhasil mendapat teteruga yang banyak. Konon batu tersebut cukup besar dan bentuknya seperti teteruga, namun karna sering dipecahkan maka ukurannya menjadi lebih kecil seperti yang tersisa sekarang ini.

Persepsi Suku Sobey Kampung Bagaiserwar terhadap Cerita batu teteruga secara umum. Berdasarkan hasil data penelitian, secara umum resepsi masyarakat Bagaiserwar terhadap batu teteruga dapat peneliti katakan masih berada dalam taraf tahu dan percaya akan kebenaran cerita beserta mitos-mitos tersebut. Meskipun dalam tingkat pemahaman dan kepercayaan yang berbeda-beda. Menurut peneliti, faktor utama yang sangat berpengaruh terhadap resepsi masyarakat Kampung Bagesserwar ini adalah faktor keyakinan agama yang mereka anut, menunjukkan bahwa seluruh penduduk Kampung Bagaiserwar beragama Kristen. Secara khusus tingkat pemahaman terhadap batu teteruga terbagi dalam dua kategori yaitu masyarakat yang perhatian yaitu masyarakat dengan kriteria mengerti, memahami, menguasai cerita dan pemakai mitos. Kedua masyarakat yang hanya menempatkan cerita Kedung Wali batu teteruga sebagai cerita masa lalu saja dan mitos-mitos tersebut sebagai hal yang tidak rasional. Pada pembahasan resepsi selanjutnya hanya akan membahas masyarakat dengan kategori pertama. Resepsi masyarakat yang perhatian kepada batu teteruga masih beragam sehingga perlu diklasifikasikan. Perbedaan resepsi tersebut dipengaruhi oleh beberapa faktor yaitu:

1. Usia

Usia merupakan faktor yang mempengaruhi tanggapan 
masyarakat Kampung Bagaiserwar terhadap mitos batu teteruga. Hal ini disebabkan oleh kurun waktu, batu teteruga merupakan peristiwa masa lampau yang hanya dialami dan diceritakan oleh masyarakat tua, maka menjadikan penguasaan cerita batu teteruga pada masyarakat generasi muda sangat minim. Hal ini dapat dimengerti, karena masyarakat generasi tua memiliki jarak lebih dekat dengan waktu terciptanya cerita. Sedangkan komunikasi dan tradisi penurunan cerita dari masyarakat generasi tua ke generasi muda kurang. Sebagian besar pewaris cerita adalah masyarakat dengan usia 40 tahun ke atas. Walaupun terdapat masyarakat muda yang mengetahui cerita akan tetapi tidak menguasai cerita. Hal itu disebabkan karena proses penurunan cerita sangat jarang dilakukan. Kalaupun ada itu hanya sebatas pengetahuan saja. Sesuai dengan pemikiran Jauss bahwa cerita dalam cerita lisan, sebuah pemahaman cerita yang didukung oleh penerimaan (di dalamnya penurunan cerita) dari generasi ke generasi. Jauss menyebutkan hal itu dengan sebutan resepsi historis (Jauss, 1982: 22). Penurunan cerita teteruga/penyu biasanya hanya terjadi dalam lingkungan sempit yaitu berkisar pada saat masyarakat yang mencari teteruga/penyu yang dilakukan setiap pencaharian teteruga saja. Itupun juga hanya dalam kapasitas yang sangat minim menceritakan batu teteruga. Itulah penyebab masyarakat generasi muda kurang memahami dan menguasai cerita batu teteruga dengan baik dan hanya dianggap sebagai cerita masa lalu saja.

2. Pendidikan

Pendidikan merupakan salah satu faktor utama yang berpengaruh pada pola pikir masyarakat Suku Sobey Kampung Bagaiserwar, dalam memahami cerita dan hal-hal yang terkait dengan batu teteruga/penyu. Pendidikan yang dimaksud tidak hanya pendidikan formal tetapi juga pendidikan non formal khususnya dalam hal ilmu agama. Masyarakat dengan tingkat pendidikan formal tinggi, tetapi pendidikan agamanya rendah menganggap cerita batu teteruga sebagai cerita masa lalu dan menempatkan mitos-mitosnya hanya sebagai tindakan biasa yang tidak mempunyai makna tertentu, karena pola pikir mereka cenderung rasional. Sedangkan masyarakat 
dengan tingkat pendidikan formal rendah, tetapi pendidikan agamanya tinggi cenderung lebih yakin akan kebenaran cerita batu teteruga/penyu karena cara berfikir mereka masih tradisional dan memposisikan sebagai pedoman keteladanan batu teteruga yang pemberi rejeki. Mereka sangat menghargai peninggalan leluhur sehingga percaya dan yakin akan mitos-mitos tersebut serta tidak berani meremehkan atau merendahkan mitos batu teteruga .

3. Pengaruh keimanan dan ketaatan beragama

Keimanan dalam hal ini dibagi menjadi dua kategori yaitu keimanan kepada hal agama dan keimanan kepada hal-hal yang bersifat mistis. Masyarakat dengan keimanan dan ketaatan yang tinggi kepada Tuhan menempatkan mitos-mitos batu teteruga sebagai sebuah kebesaran Tuhan yang diberikan berwujud batu teteruga yang memberikan tangkapan teteruga yang berlimpah. Masyarakat dengan kategori ini percaya dengan mitos ini, tetapi mereka menempatkannya sebagai perantara saja. Jadi meminta berkat dan pertolongan tetap kepada Tuhan. Sedangkan masyarakat yang cenderung mempercayai hal-hal mistis menganggap mitos teteruga sebagai kekuatan gaib, sehingga tidak heran jika ada yang melebihlebihkan cerita yang ada dalam cerita batu teteruga. Perilaku yang ditunjukkan oleh masyarakat dengan kategori demikian dapat terlihat pada saat pengambilan batu teteruga saat menjalani ritual yang dilaksanakan saat pencarian teteruga. Masyarakat dalam kategori ini yakin dengan mitos batu teteruga sehingga memperlakukan khusus ritual tersebut karena mereka menganggap hal gaib berperan lebih dari Tuhan dalam mempermudah hajat mereka.

4. Budaya

Budaya juga termasuk salah satu faktor penentu perbedaan resepsi pada masyarakat Suku Sobey di Kampung Bagaiserwar terhadap mitos batu teteruga. Masyarakat Suku Sobey yang belum banyak terpengaruh budaya luar akan menempatkan mitos batu teteruga sebagai simbol yang mencerminkan kehidupan masyarakatnya dan menganggap tradisi dan mitos itu perlu dilestarikan. Mereka akan mempercayai kebenaran mitos-mitos 
tersebut dan menganggap cerita batu teteruga/penyu benar-benar terjadi. Sedangkan masyarakat yang sudah terpengaruh budaya luar (biasanya masyarakat pendatang) akan menempatkan mitos batu teteruga hanya sebagai aktivitas biasa. Mereka tidak akan terpengaruh dan mempengaruhi keberadaan mitosmitos tersebut dalam kehidupannya. Mereka juga akan menganggap cerita batu teteruga sebagai cerita masa lalu saja. Masyarakat yang sudah terpengaruh budaya luar ini termasuk dalam kategori percaya tetapi tidak perhatian terhadap cerita batu teteruga. Masyarakat yang memberikan perhatian dikategorikan ke dalam kategori pertama karena masyarakat tersebut sampai sekarang masih melakukan pengambilan batu teteruga dalam mempermudah hajat mereka, dalam pencarian teteruga. Hal ini membuktikan bahwa masyarakat Suku Sobey masih merasa memilki dan memegang teguh mitos batu teteruga.

Fungsi Cerita batu teteruga bagi Masyarakat Suku Sobey Kampung Bagaiserwar.
Menurut Danandjaja, dilihat dari sisi pendukungnya foklor mempunyai beberapa fungsi antara lain:

1. Sebagai sistem proyeksi, yakni sebagai alat pencermin angan-angan suatu kolektif.

2. Sebagai alat pengesahan pranatapranata dan lembaga-lembaga kebudayaan.

3. Sebagai alat pendidik anak.

4. Sebagai alat pemaksa dan pengawas agar norma-norma masyarakat akan selalu dipatuhi anggota kolektifnya (Danandjaja, 1994:5).

Begitu juga dengan cerita dan mitos batu teteruga yang dimiliki oleh masyarakat Suku Sobey. Berdasarkan hasil wawancara, fungsi cerita dan mitos batu teteruga bagi masyarakat Suku Sobey Kampung Bagaiserwar sebagai pemilik cerita sekaligus penikmat mitos tersebut diantaranya adalah sebagai berikut:

a. Sebagai alat persatuan dan kesatuan, maksudnya adalah cerita batu teteruga merupakan leluhur Masyarakat Suku Sobey. Dengan adanya rasa saling memiliki cerita, mereka menjadi sadar bahwa mereka masih dalam satu keluarga, sehingga akan menimbulkan rasa 
kesetiakawanan, kerukunan, kerja sama, gotong-royong dan sikap saling menghormati diantara warga masyarakat Suku Sobey.

b. Sebagai alat pendidik, cerita dan mitos batu teteruga yang ditokohi oleh teteruga melahirkan ritual pengambilan batu teteruga saat mencari. Tradisi ini adalah sebagai alat pendidikan bagi generasi muda untuk selalu menghormati jasa-jasa orang terdahulu dan kepada orang yang lebih tua.

c. Sebagai alat pemaksa dan pengawas agar norma-norma masyarakat selalu dipatuhi anggota kolektifnya. Cerita batu teteruga yang memiliki arti bahwa masyarakat harus selalu mengingat kepada Tuhan YME dengan melaksanakan apa yang menjadi perintahNya dan menjahui segala laranganNya.

d. Sebagai media mempererat persaudaraan, artinya dari mitos batu teteruga lahirlah ritual pengambilan batu teteruga saat mencari. Dari tradisi ini menyebabkan seluruh anggota masyarakat Suku Sobey saling berinteraksi, berkomunikasi dan bekerja sama dalam rangka menyukseskan prosesi ritual tersebut. Secara tidak langsung interaksi tersebut memperat hubungan tali persaudaraan diantara mereka yang merasa dirinya bagian dari masyarakat Suku Sobey.

e. Sebagai sistem proyeksi, yakni sebagai alat pencermin anganangan suatu kolektif, dalam hal ini masyarakat Suku Sobey Kampung Bagaiserwar. Maksudnya adalah cerita batu teteruga ini ditindaklanjuti dengan pengambilan batu teteruga tersebut. Mayoritas Masyarakat Suku Sobey mempercayai bahwa batu teteruga adalah batu yang bertuah, berkhasiat. Dengan pengambilan batu teteruga/penyu, mereka berharap dapat membantu hajat mereka. Tetapi bukan berarti melakukan perbuatan syirik yang dilarang oleh ajaran agama Kristen karena mereka mengambil batu teteruga tersebut hanya sebagai perantara saja, memohon dan berdoanya tetap kepada Tuhan YME.

Relasi dan keterkaitan antara cerita rakyat dan tinggalan megalitik batu teteruga, dinilai oleh Suku Sobey sebagai fenomena yang sama dan saling berkaitan. Pandangan 
dan persepsi masyarakat yang berada di Sarmi dan daerah sekitarnya, sangat menyakini bahwa batu megalitik tersebut yang berada di daerah Bagaiserwar merupakan wujud dari teteruga yang berubah menjadi batu. Secara ilmiah fenomena ini tentunya tidak bisa diterima begitu saja tanpa didasari hipotesa dan analisa yang jelas.

Untuk melihat hubungan antara cerita rakyat dan tinggalan megalit batu teteruga diperlukan sebuah proses penelitian dan kajian menyeluruh yang didukung oleh data-data etnografi yang kuat. Proses dasar tersebut diharapkan dapat mengungkap dan mengidentifikasi makna-makna yang tersembunyi di dalam kisah cerita yang disampaikan, diperbandingkan dengan realita budaya yang ada dalam masyarakat pendukung legenda tersebut. Oposisi yang muncul dapat membantu memetakan relasi dari unsur-unsur yang ada.

Kebudayaan megalitik batu teteruga ini menghasilkan bentuk budaya materi yang terbuat dari batu monolit. Batu teteruga tersebut memberi pengetahuan yang tinggi kepada kita mengenai bentuk aktivitas masa lalu. Sejumlah budaya materi yang tercipta menyiratkan aktivitas yang senantiasa mengutamakan sumber daya alam yang tersedia. Temuan batu megalitik di 106
Bagaiserwar ini menunjukan gambaran adanya kemajuan teknologi dalam mengeksploitasi sumberdaya alam yang cukup banyak tersedia di sekitar mereka. Konsep pemikiran ini dilandasi oleh pencapaian tujuan (baik religi maupun sosial) yang mereka ciptakan sendiri untuk memenuhi kebutuhannya. Keberadaan hasil budaya megalitik batu teteruga ini tercipta oleh adanya kehidupan yang terorganisir.

Wilayah Papua merupakan suatu daerah yang memiliki bentuk budaya megalitik dan tersebar di berbagai wilayah termasuk di wilayah Kabupaten Sarmi. Baik bentuk maupun korelasinya dengan sumber daya alam serta berbagai nilai-nilai leluhur adalah data yang sangat mendasar untuk mengetahui berbagai bentuk aktivitas manusia masa lampau. Kebudayaan megalitik dengan berbagai corak dan nilainilai yang terkandung di dalamnya merupakan gambaran betapa kayanya peninggalan arkeologis di daerah Papua yang dapat dijadikan dasar dari bentukbentuk awal peradaban manusia sekitar awal Masehi. Kehadiran kebudayaan megalitik memberi corak kehidupan tersendiri yang mengetengahkan nilai atau falsafah masyarakat masa lampau yang diaktualisasikan melalui penataan budaya megalitik, yang terdiri atas pemikiran Batu Teteruga Dan Cerita Rakyat Suku Sobey 
penentuan pusat wilayah suatu daerah, adanya relasi kuasa dalam pendirian monumen megalitik, dan corak masyarakat agraris. Situs-situs megalitik di Papua pernah menjadi tempat permukiman suatu komunitas yang memiliki kemampuan mengadaptasi lingkungannya.

Secara logika dan ilmiah, memang sulit menerima cerita rakyat yang dikategorikan dongeng atau mitos, dan bahkan dianggap sebagai hiburan pengantar tidur, dijadikan dasar yang mendukung sebuah analisa untuk menjawab proses kemunculan tinggalan megalitik di Kampung Bagaserwar, Kabupaten Sarmi. Saat ini ada dua saluran yang digunakan sebagai media pewarisan dan penyebaran kisah legenda batu teteruga. Pertama adalah cerita teteruga yang disampaikan melalui tutur secara lisan. Kedua, cerita batu teteruga disampaikan melalui tulisan.

Terkait tinggalan megalitik yang ditemukan di Kampung Bagaiserwar dapat mengungkapkan cerita rakyat Suku Sobey di Kabupaten Sarmi. Cerita batu teteruga tersebut merupakan cerita turun-temurun, yang memiliki nilai-nilai ajaran etika yang sangat bermanfaat bagi proses terbentuknya karakter bangsa. Pada masa sekarang etika generasi mudah mulai menurun, hal itu bila dibiarkan membawa kehancuran bangsa.
Identitas bangsa Indonesia yang mengacu pada adat ketimuran akan bergeser begitu saja. Oleh sebab itu, perlu dilakukan adanya penanaman etika kepada generasi penerus, melalui cerita-cerita rakyat. Cerita rakyat salah satu media yang bisa dimanfaatkan sebagai sarana membangun karakter positif pada generasi muda, melalui nilai-nilai moral dan pendidikan karakter yang terkandung dalam cerita rakyat itu sendiri.

Cerita rakyat batu teteruga ini apabila diwariskan dan ditanamkan pada generasi penerus akan membangun karakter, yang mengarah pada hal-hal positif. Penanaman etika yang baik tentunya dapat membangun watak, sikap dan prilaku yang memperkuat soft kill untuk menanamkan kebiasaan-kebiasaan baik. Melalui para tokoh yang ada dalam cerita dapat disampaikan sikap, prilaku dan tutur kata tokoh yang mencerminkan etika maupun moral.

Dari uraian cerita batu teteruga tersebut, ada khasanah nilai budaya yang tersirat, dan pesan moral yang dapat di petik diantaranya:

1. Nilai budaya.

Nilai budaya yang terkandung dalam cerita rakyat batu teteruga ini berkaitan dengan etos kerja yang meliputi kerja keras, ketekunan, 
ketaatan, dan kesabaran. Dalam kisah cerita batu teteruga ini mereka bekerja keras, tekun, taat dan sabar, mencari atau menangkap teteruga sehingga dengan kerja kerasnya ia dapat memiliki tangkapan yang terbaik, atau banyak. Sehingga teteruga yang didapat tersebut dapat dinikmati oleh mereka bahkan masyarakat yang berada disekitarnya.

2. Nilai sosial.

Nilai sosial yang tercermin dari cerita batu teteruga ini, yang diyakini oleh masyarakatnya bahwa cerita tempat batu teteruga ini benarbenar ada. Batu monolit ini dipercaya membawa rezeki melalui pengambilan batu teteruga. Nilai sosial yang bisa di ambil yaitu dapat memberi kesejahteraan kepada orang banyak.

3. Nilai Konseptualisasi.

Nilai konseptual yang dimaksud adalah pengertian, pendapat atau penafsiran akan sesuatu yang mungkin terjadi. Demikian halnya dalam cerita batu teteruga ini dalam konseptualisasi bahwa manusia hidup sangat saling ketergantungan, baik antar individu, manusia dengan makluk ciptaan Hidup selaras, harmonis, dan saling menghargai. Kesadaran akan pentingnya alam sekitar seperti halnya peran sebuah batu teteruga pada kehidupan manusia memberi kehidupan pada manusia, namun sebaliknya bila batu teteruga tidak dijaga tidak dilestarikan maka batu tersebut akan habis karena selalu diambil sedikit demi sedikit untuk di bawah dalam pencarian teteruga tersebut.

4. Nilai Religi

Selain itu cerita batu teteruga memiliki nilai religius, yakni masyarakat percaya akan adanya kekuatan gaib atau roh nenek moyang yang mendiami batu teteruga tersebut. Mereka percaya dengan mengambil dan mengadakan ritual pada batu teteruga, mereka akan diberkati dengan mendapat tangkapan teteruga yang banyak.

Dari cerita tersebut merupakan inspirasi yang menarik untuk dieksplor dan diekspos pada khalayak umum sebagai khasanah pengembangan ilmu budaya, yang merupakan perbendaharaan pemikiran warisan nenek moyang yang berguna juga untuk masa sekarang yang 
juga sebagai alat pendidik kepada generasi muda dan masyarakat umumnya. pengokoh nilai-nilai sosial budaya, dan pengontrol kehidupan sosial.

\section{PENUTUP}

Tinggalan megalitik berkaitan dengan cerita rakyat batu teteruga/ penyu di temukan di kampung Bagaiserwar Distrik Sarmi Kota Kabupaten Sarmi Provinsi Papua. Batu tersebut adalah batu monolit, yang berada di pesisir pantai merupakan batu pasir berwarna hitam keabuan dengan panjang $160 \mathrm{~cm}$, lebar $140 \mathrm{~cm}$ dan tebal 70 $\mathrm{cm}$, bagian permukaan batu datar dan terdapat lubang-lubang bulat di atasnya. Batu tersebut dipercaya sebagai teteruga yang berubah wujud. Tinggalan megalit batu teteruga adalah kebudayaan materi (material culture) yang merupakan suatu produk manusia masa lampau yang mempunyai makna dan nilai, karena pernah "hidup" di tengah masyarakat, khususnya pada masyarakat Sarmi. Tinggalan tersebut didalamnya tergambar berbagai sistem diantaranya adalah sistem sosial dan religi yang harus diungkapkan. Dengan kajian yang mendalam terhadap kebudayaan materi melalui ceria rakyat, maka nilai-nilai yang melekat dapat diungkapkan. Cerita batu teteruga tersebut mempunyai kegunaan sebagai suatu bentuk hiburan, sarana pendidikan, penggalang rasa kesetiakawanan 


\section{DAFTAR PUSTAKA}

Danandjaja, James. 2007. Folklore Indonesia, Ilmu gossip, Dongeng dan lain-lain. Jakarta PT Temprint.

Geldern, R. Von Heine. 1984. Prehistoric Research in The Netherland Indies, Science and Scientists in The Netherland Indie, P.124-167. Pieter Honing, PhD, and Frans Verdoor (ed) New York.

Hoop, A.N.J. Th. Van der, 1932. Megalithik Remains in South Sumatra. Tranlated by $W$. Shirlaw, Zuthpen. W. J. Thieme \& Cie.

Lestari, Ria Fatimah Ummu. 2012. Mengungkapkan Cerita Rakyat Berdasarkan Temuan Purbakala di Pulau Ormu Kabupaten Jayapura. Jayapura Papua Jurnal Penelitian Arkeologi Papua dan Papua Barat. Vol 9 No 1 Juni. Balai Arkeologi Jayapura Kementerian Kebudayaan dan Pariwisat

Lekitoo, Y. Hanro dan Djoht Djekky. 2004. Sejarah Kota Sarmi. Kerja sama pemerintah Kabupaten Sarmi dan Laboratoium Universitas Cenderawasih

Maryone, Rini. 2016. Penelitian Arkeologi Peralatan Hidup Suku-Suku Yang Berada Di Kabupaten Sarmi, Laporan Penelitian Arkeologi. Balai Arkeologi Papua.

Maryone, Rini. 2014. Megalitik Dan Cerita Rakyat Suku Baham Di Gua Sosoraweru Fakfak. Jurnal Penelitian Arkeologi Papua Dan Papua Barat. Vol 6 Edisi 2 November. Balai Arkeologi Jayapura Kementerian Kebudayaan dan Pariwisata.

Maryone, Rini. 2019. Batu Mawe Di Teluk Wondama. Jurnal Penelitian Arkeologi Papua dan Papua Barat.Vol 11 No 2 November. Balai Arkeologi Jayapura Kementerian Kebudayaan dan Pariwisata.

Maryone, Rini. 2019. Tinggalan Megalit Batu Sukun Mengungkapkan Cerita Rakyat Di Kampung Yapase. Jurnal Penelitian Arkeologi Papua Dan Papua Barat. Vol 11 edisi 1 Juni Balai Arkeologi Jayapura Kementerian Kebudayaan dan Pariwisata.

Prasetyo, Bagyo. 2011. Yogyakarta. Budaya Pantai dan Pedalaman Masa Prasejarah di Papua dalam Austronesia dan Melanesia di Nusantara, mengungkapkan Asal-usul dan Jati diri dari Temuan Arkeologis. Yogyakarta: Penerbit Ombak kerjasama dengan Balai Arkeologi Jayapura.

Prasetyo, Bagyo. 2015. Pernak-Pernik Megalitik Nusantara. Kementerian Pendidikan dan Kebudayaan Badan Penelitian dan Pengembangan Pusat Penelitian Arkeologi Nasional.

Soejono, R.P. 1984. “Jaman Prasejarah di Indonesia,” dalam Sejarah Nasional Indonesia, Vol. I.PN Balai Pustaka, Jakarta.

Soejono, R.P. (ed.). (1984). Sejarah Nasional Indonesia I. Jakarta: Balai Pustaka.

Jurnal Arkeologi Papua Vol. 13 Edisi No. 1 / Juni 2021 : 95-114 
Sumarsih, S. 1985. Risalah Sejarah dan Budaya, Seri Terjemahan Naskah Kuno, Departemen Pendidikan dan Kebudayaan, Direktorat Jendral Kebudayaan, Balai Kajian Sejarah dan Nilai Tradisional. Yogyakarta.

Wibowo, Bayu Ari. 2015. Pemakalah Lingga-Yuni dan masyarakat Jawa-Hindu di Kabupaten Banyuwangi Provinsi Jawa Timur. Studi Etnoarkeologi. Skripsi. Denpasar. UNUD. 